\title{
Molecular characterization and genetic diversity of Jatropha curcas L. in Costa Rica
} \author{
Ilenana Moreira ${ }^{5}$, Elizabeth Arnáez ${ }^{6}$, Natalia M Barboza ${ }^{\text {Corresp. } 1,7,8}$ \\ ${ }^{1}$ Centro de Investigación en Biología Celular y Molecular, Universidad de Costa Rica, San Pedro, San José, Costa Rica \\ 2 Escuela de Biología, Universidad de Costa Rica, San Pedro, San José, Costa Rica \\ 3 Estación Experimental Fabio Baudrit Moreno, Universidad de Costa Rica, Alajuela, Costa Rica \\ 4 Ministerio de Agricultura y Ganadería, San José, Costa Rica \\ 5 Escuela de Biología, Instituto Tecnológico de Costa Rica, Cartago, Costa Rica \\ 6 Escuela de Biología, Instituto Tecnológico de Costa Rica, Cartago, Cartago, Costa Rica \\ 7 Escuela de Tecnología de Alimentos, Universidad de Costa Rica, San Pedro, San José, Costa Rica \\ 8 Centro Nacional en Ciencia y Tecnología de Alimentos, Universidad de Costa Rica, San Pedro, San José, Costa Rica \\ Corresponding Author: Natalia M Barboza \\ Email address: natalia.barboza@ucr.ac.cr
}

Marcela Vásquez-Mayorga ${ }^{1}$ ， Eric J Fuchs ${ }^{2}$ ， Eduardo J Hernández ${ }^{1}$ ， Franklin Herrera ${ }^{3}$ ， Jesús Hernández ${ }^{4}$,

We estimated the genetic diversity of 50 Jatropha curcas samples from the Costa Rican germplasm bank using 18 EST-SSR, one G-SSR and nrDNA-ITS markers. We also evaluated the phylogenetic relationships among samples using nuclear ribosomal ITS markers. Nontoxicity was evaluated using G-SSRs and SCARs markers. A Neighbor-Joining (NJ) tree and a Maximum Likelihood (ML) tree were constructed using SSR markers and ITS sequences, respectively. Heterozygosity was moderate $(\mathrm{He}=0.346)$, but considerable compared to worldwide values for $J$. curcas. The PIC (PIC $=0.274)$ and inbreeding coefficient $(f=-0.102)$ were both low. Clustering was not related to the geographical origin of accessions. International accessions clustered independently of collection sites, suggesting a lack of genetic structure, probably due to the wide distribution of this crop and ample gene flow. Molecular markers identified only one non-toxic accession (JCCR-24) from Mexico. This work is part of a countrywide effort to characterize the genetic diversity of the Jatropha curcas germplasm bank in Costa Rica. 
1 Molecular characterization and genetic diversity of Jatropha curcas L. in Costa Rica

2 Marcela Vásquez-Mayorga ${ }^{1}$, Eric J. Fuchs ${ }^{2}$, Eduardo J. Hernández ${ }^{1}$, Franklin Herrera ${ }^{3}$, Jesús

3 Hernández ${ }^{4}$, Ileana Moreira ${ }^{5}$, Elizabeth Arnáez ${ }^{5}$, Natalia Barboza ${ }^{1,6,7}$

41 Centro de Investigación en Biología Celular y Molecular, Universidad de Costa Rica, San José,

5 Costa Rica

62 Escuela de Biología, Universidad de Costa Rica, San José, Costa Rica

73 Estación Experimental Fabio Baudrit Moreno, Universidad de Costa Rica, Alajuela, Costa Rica

84 Ministerio de Agricultura y Ganadería, Costa Rica, San José, Costa Rica

95 Escuela de Biología, Instituto Tecnológico de Costa Rica, Cartago, Costa Rica

106 Escuela de Tecnología de Alimentos, Universidad de Costa Rica, San José, Costa Rica

117 Centro Nacional en Ciencia y Tecnología de Alimentos, Universidad de Costa Rica, San José,

12 Costa Rica

14 Corresponding Author:

15 Natalia Barboza

16 Ciudad de la Investigación, San Pedro, San José, 11501-2060 Costa Rica

17 Email address: natalia.barboza@ucr.ac.cr 


(

\section{ABSTRACT}

We estimated the genetic diversity of 50 Jatropha curcas samples from the Costa Rican germplasm bank using 18 EST-SSR, one G-SSR and nrDNA-ITS markers. We also evaluated the phylogenetic relationships among samples using nuclear ribosomal ITS markers. Non-toxicity was evaluated using G-SSRs and SCARs markers. A Neighbor-Joining (NJ) tree and a Maximum Likelihood (ML) tree were constructed using SSR markers and ITS sequences, respectively. Heterozygosity was moderate $(\mathrm{He}=0.346)$, but considerable compared to worldwide values for $J$. curcas. The PIC (PIC $=0.274)$ and inbreeding coefficient $(f=-0.102)$ were both low. Clustering was not related to the geographical origin of accessions. International accessions clustered independently of collection sites, suggesting a lack of genetic structure, probably due to the wide distribution of this crop and ample gene flow. Molecular markers identified only one non-toxic accession (JCCR-24) from Mexico. This work is part of a countrywide effort to characterize the genetic diversity of the Jatropha curcas germplasm bank in Costa Rica.

(1)

(1)


42

43

\section{INTRODUCTION}

The use of fossil fuels for energy production is being discouraged because of global warming and fluctuating market prices. This situation has motivated research on alternative fuel sources such as biodiesel from corn or palm oil (To \& Grafton, 2015). Jatropha curcas is being explored as a new biofuel crop (Islam et al., 2013). It is planted on approximately 1.8 million ha in Indonesia, China, Brazil and Africa, and has the potential to become a biofuel crop in India and other tropical countries (Carels, 2013). J. curcas, a member of the Euphorbiaceae family, is native to America and has a pantropical distribution. It grows well under unfavorable climatic and soil conditions, making it an attractive biofuel crop. Average oil content per seed is $40-45 \%$ (Jongschaap et al., 2007). Biofuel from this species is similar in quality to biofuels derived from conventional crops like canola, linseed and sunflower, and surpasses the quality of biofuels produced from soybean (Basili \& Fontini, 2012).

The potential of $J$. curcas has not been fully exploited, mainly because of its variable and unpredictable oil yield that limits large-scale cultivation. Genetic improvement may alleviate this problem; however, characterization of the available germplasm is needed for breeding programs to be efficient (King et al., 2015; Mastan et al., 2012). Over the past decade, J. curcas germplasm has been genetically evaluated in India, China, Brazil, Mexico, Costa Rica and Central America (Avendaño et al., 2015; Basha \& Sujatha, 2007; China Plant BOL Group et al., 2011; Montes Osorio et al., 2014; Pecina-Quintero et al., 2014; Rosado et al., 2010; Wen et al., 2010). Molecular markers such as RAPDs, ISSRs, AFLPs, genomic simple sequence repeats (G-SSR) and expressed sequence tags-SSR (EST-SSR) have all been used to assess the genetic diversity of $J$. curcas collections. These studies have revealed low levels of genetic variability in India and Brazil (China Plant BOL Group et al., 2011; Rosado et al., 2010; Sun et al., 2008; Yadav et al., 2011). Numerous 
65 authors consider Mexico and Central America to be the center of origin and diversification 66 (Abdulla et al., 2009; Basha et al., 2009; Heller, 1996; Openshaw, 2000; Pamidimarri, 67 Chattopadhyay \& Reddy, 2008; Pamidimarri \& Reddy, 2014; Pecina-Quintero et al., 2011; 68 Tatikonda et al., 2009), and high levels of genetic diversity in Guatemala (Raposo et al., 2014) and Mexico support this hypothesis (Ambrosi et al., 2010; Ovando-Medina, Adriano-Anaya \& Vásquez-Ovando, 2013; Ovando-Medina et al., 2011; Pamidimarri \& Reddy, 2014; PecinaQuintero et al., 2011). However, these studies have consistently shown a lack of relationship between the geographic proximity of collection sites and the genetic similarity among accessions, because collection sites rarely represent the place of origin of accessions.

Another limitation to large-scale production of J. curcas is the possible toxicity of the seed. Both toxic and non-toxic genotypes of $J$. curcas are known (Insanu et al., 2013). Varieties with a nontoxic seed cake would be more readily accepted by local farmers because sub-products of the oil extraction process could be utilized for animal feeding (Makker \& Becker, 2015). Therefore, it is important to evaluate materials stored in germoplasm banks for non-toxicity. Non-toxic genotypes have been described in Mexican accessions (Vera-Castillo et al., 2014). As with variation in toxicity, genotypes with variable seed oil content and number of seeds may surface in other Latin American regions and contribute to $J$. curcas breeding programs all over the world.

In the past decade, SSR markers have proven useful for the analysis of genetic diversity. Simple sequence repeats that identify variability in transcribed genomic regions can be found in EST libraries. They may facilitate the identification of functional candidate genes, increase the efficiency of marker-assisted selection and serve as markers for comparative mapping (Varshney, Graner \& Sorrells, 2005). Nuclear ribosomal-DNA internal transcribed spacers (nrDNA ITS) are sequence-based markers that have been used in phylogenetic studies and to assess genetic diversity 
88 at the species level in a wide range of taxonomic groups (Nieto-Feliner \& Roselló, 2007). ITS

89 markers have been developed for J. curcas (Pecina-Quintero et al., 2011) and are believed to have

90 greater discriminatory capacity than plastid $r b c L$ and matK markers (China Plant BOL Group et

91 al., 2011). SSR and ITS markers used together allow for a better understanding of the evolutionary

92 history of undomesticated species such as J. curcas.

93 Prior to the current study, the genetic variability of the Costa Rican J. curcas germplasm bank had 94 not been studied. The present study explores the molecular diversity of accessions using EST-SSR 95 and G-SSR markers and evaluates the phylogenetic relationships between them using nuclear 96 ribosomal ITS markers. Alleles associated with $J$. curcas toxicity were also evaluated with G97 SSRs and sequence characterized amplified region (SCAR) markers.

\section{MATERIALS \& METHODS}

\section{DNA collection and extraction}

The germplasm bank of Jatropha curcas in Costa Rica includes accessions from Honduras, Brazil, India, Mexico, El Salvador, Ecuador, Uganda, Colombia and South Africa. Costa Rican accessions include only spontaneously occurring individuals collected in the field and vegetatively propagated. The collection does not include material from commercial plantations (Fig. 1). International accessions originated from seeds collected from spontaneously occurring plants in each country. All accessions are maintained by vegetative propagation in the germplasm bank located at the Fabio Baudrit Experimental Station (1000'10.3"N, 84¹6'17.6"W) at Universidad de Costa Rica.

For genetic analysis, two young leaves were collected from each of 50 plants representing different accessions in the germplasm bank (Table 1). Vegetative material was frozen and later lyophilized 
111 for DNA extraction. Nucleic acids were extracted using the Möller et al. (1992) protocol and 112 quantified using a Nanodrop (Thermo Scientific).

113

\section{SSR analysis}

115 Eighteen EST-SSRs and one G-SSR marker (Wen et al., 2010) were used to analyze the 50 samples 116 (Table 2). PCR was performed in a final volume of $25 \mu \mathrm{L}$ with 1 X PCR buffer, $400 \mu \mathrm{M}$ dNTPs, $0.4 \mu \mathrm{M}$ of each primer, and $1 \mathrm{U}$ Taq DNA polymerase (Thermo Scientific). Amplification conditions included an initial denaturation at $94{ }^{\circ} \mathrm{C}$ for $1 \mathrm{~min}$, followed by 35 cycles of $94{ }^{\circ} \mathrm{C}$ for $1 \mathrm{~min}, 42-50{ }^{\circ} \mathrm{C}$ for $1 \mathrm{~min}$ (depending on the annealing temperature of each primer pair) and 72 ${ }^{\circ} \mathrm{C}$ for $1 \mathrm{~min}$, with a final extension of $72{ }^{\circ} \mathrm{C}$ for $10 \mathrm{~min}$. Results were visualized in 4-6\% polyacrylamide gels dyed with silver nitrate. To confirm the results, duplicates of $10 \%$ of the samples were made. Acrylamide gels were scored manually in the GNU Image Manipulation Program (www.gimp.org) and a data matrix with band size data was created. The SSRs were scored according to amplicon size. The software Microchecker was used to test for null alleles and allelic dropout (van Oosterhout et al., 2004).

126

\section{nrDNA-ITS region amplification and sequencing}

ITS primers were used to elucidate phylogenetic relationships between accessions. The primer pair

JCITS-1-F (5'-ACCTGCGGAAGGATCATTGTCGAAA-3') and JCITS- 2-R (5'CCTGGGGtCGCGATGTGAGCGT 3') was used (Pamidimarri, Chattopadhyay \& Reddy, 2008 ) in a PCR reaction with a final volume of $25 \mu \mathrm{L}$ and a final concentration of $1 \mathrm{X}$ reaction buffer, $1.5 \mathrm{mM} \mathrm{MgCl}_{2}, 0.2 \mu \mathrm{M}$ of each primer, $0.2 \mathrm{mM}$ dNTPs, $1 \mathrm{U}$ Taq DNA polymerase

133 (Thermo Scientific) and $50 \mathrm{ng}$ of DNA. The PCR program consisted of an initial denaturation step 
134 of $94{ }^{\circ} \mathrm{C}$ for $1 \mathrm{~min}$, followed by 30 cycles of $40 \mathrm{~s}$ at $94{ }^{\circ} \mathrm{C}, 65^{\circ} \mathrm{C}$ for $1 \mathrm{~min}$ and $72{ }^{\circ} \mathrm{C}$ for $1 \mathrm{~min}$.

135 The final extension step was $5 \mathrm{~min}$ at $72{ }^{\circ} \mathrm{C}$. The PCR products were sent to Macrogen ${ }^{\circledR}$ for 136 sequencing. The obtained sequences were aligned and submitted to Genbank (www.ncbi.com).

\section{Data analysis}

139 Genetic diversity was quantified as the expected heterozygosity, the Polymorphism Information

140

141

142

143

144

145

146

147

148

149

150

151

152

153

154

155

156 content (PIC) and the inbreeding coefficient $(f)$. The PIC index describes the probability that two random accessions would have different alleles at a random locus (Smith et al., 2004). All estimates were calculated using the Powermarker 3.25 software (Liu \& Muse, 2005). The validity of all estimates was assessed by means of 50000 bootstraps.

To determine the genetic relation between accessions, we calculated the $\delta \mu^{2}$ genetic distance between accessions using the POPULATIONS software (http://bioinformatics.org/ tryphon/populations/). The $\delta \mu^{2}$ metric developed by Goldstein et al. (1995) is based on the stepwise mutation model and estimated distances are a linear function of divergence time; this distance is preferred for taxa that have diverged widely (Goldstein et al., 1995). We used the distance matrix to construct a Neighbor-Joining (NJ) tree using the default parameters in POPULATIONS. The standardized genetic distance matrix was also used to perform a Principal Coordinates Analysis (PCA) in GenAlEx 6.5 (Peakall \& Smouse, 2012).

For phylogenetic analysis, ITS sequences for J. curcas samples from Mexico, India, Cape Verde, Spain, Africa and Madagascar were downloaded from GenBank (http:/www.ncbi.nlm.nih.gov). Sequences from Costa Rican samples were edited with BioEdit software version 7.2.5 and aligned using the MAFFT algorithm in the GUIDANCE server. To compare the phylogenetic relationship of GenBank sequences with those from the Costa Rican J. curcas germplasm bank, we initially 
157

158

159

160

161

162

163

164

165

166

167

168

169

170

171

172

173

used jModelTest 2.1.7 (Santorum et al., 2014) to define the optimum substitution model for all sequences and the GTR model (Tavaré, 1986) with uniform rates was chosen. A maximum likelihood (ML) tree was constructed with 3000 bootstrap replications and expressed as the number of base substitutions per site using MEGA 6.0 (Tamura et al., 2013).

\section{Toxicity evaluation}

Plant toxicity was evaluated by the presence of alleles from three SSR markers associated with lack of toxicity (Table 3) (Vischi, Raranciuc \& Baldini, 2013). PCR amplification was achieved in a final volume of $25 \mu \mathrm{L}$ with a final concentration of $1 \mathrm{X}$ reaction buffer, $1.5 \mathrm{mM}$ of $\mathrm{MgCl}_{2}, 0.2$ $\mu \mathrm{M}$ of each primer, $0.2 \mathrm{mM}$ dNTPs, $1 \mathrm{U}$ Taq DNA polymerase (Thermo Scientific) and $50 \mathrm{ng} / \mu 1$ DNA sample. The PCR program had an initial denaturation of $94{ }^{\circ} \mathrm{C}$ for $1 \mathrm{~min}, 30$ cycles of $40 \mathrm{~s}$ at $94{ }^{\circ} \mathrm{C}, 65{ }^{\circ} \mathrm{C}$ for $1 \mathrm{~min}, 72{ }^{\circ} \mathrm{C}$ for $1 \mathrm{~min}$ and a final extension of $5 \mathrm{~min}$ at $72{ }^{\circ} \mathrm{C}$. Results were visualized by genotyping with fluorescent dyes (FAM, VIC and PET) (Vischi, Raranciuc \& Baldini, 2013) in a 3130 sequencer (Applied Biosystems). Two SCAR markers (ISPJ1 and ISPJ2) were also used to evaluate alleles for toxicity in all accessions following the protocol of Basha \& Sujatha (2007). ISPJ1 amplifies a 543 bp fragment and is specific for toxic genotypes, while ISPJ2 is specific for non-toxic genotypes and amplifies a $1096 \mathrm{bp}$ fragment. Results were visualized in a $2 \%$ agarose gel run for one hour and dyed with GelRed (Biotium). Plants were scored as toxic or non-toxic based on the presence and size of amplicons.

\section{RESULTS}

Genetic diversity analysis 
179 Genetic diversity was estimated using 18 SSR-ESTs and one G-SSR marker. Average 180 heterozygosity $(\mathrm{He})$ was $0.346 \pm 0.062( \pm \mathrm{SD})$. Polymorphism information contents (PIC) ranged 181 from 0.042 to 0.677 , with a mean PIC of $0.274 \pm 0.165$. We did not find evidence of inbreeding $f$ $182=-0.102 \pm 0.346($ Table 4$)$.

The NJ tree did not show a clear clustering pattern (Fig. 2) and clusters did not reflect geographic proximity. Accessions from countries located in close proximity such as Colombia (JCCR-38) and Ecuador (JCCR-25) did not seem to be genetically close to each other. In contrast, samples from distant locations clustered together, for example, India (JCCR-INDIA) and Costa Rica (JCCR-14); South Africa (JCCR-47) and Honduras (JCCR-2); Brazil (JCCR-16) and Costa Rica (JCCR-MIR); and Mexico (JCCR-24) and Ecuador (JCCR-25). Within Costa Rica, there was no evidence of geographic structure. Samples collected from sites separated by more than $300 \mathrm{~km}$ grouped together (JCCR-20, JCCR-7).

Our PCA analysis produced comparable results. Genetic information accounted for $41.26 \%$ of the observed variance; the first two components explained $19.17 \%$ and $11.86 \%$ of the total variance, respectively. We did not observe distinct groups of accessions in a biplot of the first two components (Fig. 3). Accessions from the same country did not group together, such as those from Mexico (JCCR-24 and JCCR-31) and India (JCCR-INDIA and JCCR-27 INDIA). Costa Rican accessions were scattered throughout the plot without any discernible pattern. These results were congruent with our $\mathrm{NJ}$ tree.

\section{nrDNA-ITS sequence analysis}

As with the NJ and PCA analysis, the observed patterns from the Maximum Likelihood (ML) tree did not reflect the geographic origin of the accessions (Fig. 4) and in most cases, the clades grouped in polytomies. International and Costa Rican accessions from this research were scattered 
throughout the tree (JCC-38, JCCR-2, JCCRLEP, JCCR33-1, JCCR31, JCCR21, JCCR19, JCCR9, JCCR8, JCCR7, JCCR3), they grouped with sequences from Mexico and with individuals from Spain, Cape Verde, Africa and Madagascar (GenBank accession numbers EU700449, EU70055, EU70046, EU70045, respectively). It is important to mention that the observed clustering of germplasm independent of geographical origin could be an artifact of unequal sampling, as the majority of the samples used in this research were from Costa Rica and only one or two representatives from each of the other countries were included.

\section{Toxicity evaluation}

A single Mexican accession (JCCR-24) was identified as non-toxic by the SSR primer set (JCT31, JCT-27 and JcSSR-26) and both SCAR primers ISPJ1 and ISPJ2. ISPJ1 also identified nontoxic genotypes in two other accessions: JCCR-32 and JCCR-43. Using ISPJ2, accessions JCCR22 and JCCR25 were identified as non-toxic. These results need to be corroborated using in vivo assays.

\section{DISCUSSION}

\section{Genetic diversity of Jatropha curcas}

Our study is the first to provide genetic diversity estimates for Costa Rican J. curcas samples. Based on morphological and molecular evidence, different authors support the idea that Mexico and Central America may be the center of origin and diversification for J. curcas (Pamidimarri \& Reddy, 2014; Pecina-Quintero et al., 2014). Pecina-Quintero et al. (2014) found high genetic diversity of $J$. curcas in Mexico. Grativol et al. (2010) analyzed 332 accessions from 12 locations in Brazil using ISSR primers and reported lower genetic diversity than that reported in Mexico. Pamidimarri \& Reddy (2014) used RAPD and AFLPs to analyze the molecular diversity of 42 
226 Indian accessions of $J$. curcas and found a mean percentage of polymorphism (PP) of 26.47. In 227 the same study, the average PP of Mexican accessions was 33.18. The mean PP of the germplasm samples excluding the Indian accessions was 35.86, supporting the hypothesis that Indian germplasm is less diverse than germplasm in other regions of the world (Colombo, Second \& Charrier, 2000; Ram, Kumar \& Bhatt, 2004). Montes et al. (2014) also found higher genetic diversity in Mexican and Central American accessions compared to those from other parts of the world. Given the observed levels of genetic diversity, Costa Rica may be a secondary center of origin or diversification for this species (Pamidimarri \& Reddy 2014; Pecina-Quintero et al., 2014). However, comparisons are limited since few studies have evaluated genetic diversity of $J$. curcas germplasm using EST-SSR markers. Wen et al. (2010) evaluated 45 accessions from Indonesia, Grenada, South America and two Chinese provinces, and found a mean genetic diversity of 0.3819 . The most diverse locations were South America and Yunnan with $\mathrm{H}=0.33$ and $\mathrm{H}=0.3473$, respectively. In another study, 50 EST-SSR markers were used to evaluate 25 Indian accessions and an average He of 0.30 was found (Yadav et al., 2011). As in our study, accessions clustered independently of geographic origin. Our PIC estimates $(\mathrm{PIC}=0.274 \pm 0.165)$ were comparable to those obtained by Yadav et al. $(2011)(\mathrm{PIC}=0.25 \pm 0.16)$ and are considered moderately informative (Botstein et al., 1980).

In Costa Rica, Jatropha curcas is typically not cultivated commercially. Plants usually grow as hedgerows and are occasionally reproduced by farmers through cuttings. Our samples represent plants growing spontaneously in the field; no commercially grown material was included in the study. Therefore, our genetic diversity estimates represent the standing natural variation of this species. However, since EST-SSR markers were developed from expressed sequence tag libraries, they reside within genes and are subject to selection, which reduces unfavorable polymorphisms 
249 (Cova et al., 2012; Ellis \& Burke 2007). EST-SSR markers are less polymorphic than genomic 250 SSRs (Song et al., 2012) and consequently, genetic diversity may have been underestimated in this 251 study. J. curcas is a predominantly outcrossing species $(\mathrm{tm}=0.683)($ Bressan et al., 2013). As 252 expected, we found no significant evidence of inbreeding $(f=-0.102)$. High rates of gene flow should produce low levels of inbreeding, which would result in the low structure suggested by our NJ and ML clustering. Low inbreeding coefficients were also estimated in Mexico and South America (Ambrosi et al., 2010). Although inbreeding was negligible in the present study, in other parts of the world such as India and Brazil, lower genetic diversity has been attributed to increased selfing or a high paternity correlation due to the spread of introductions across the country through vegetative propagation, recent common ancestry, drift, and intensive selection of the currently cultivated materials since the time of introduction (Basha \& Sujatha, 2007; Bressan et al., 2013; Rosado et al., 2010).

\section{Phylogenetic analysis of Jatropha curcas}

Several studies of $J$. curcas have shown that collection sites do not necessarily reflect the genetic origin of accessions (Ambrosi et al., 2010; Maghuly et al., 2015). Our NJ tree and PCA analysis (Fig.2 and Fig.3) showed no correlation between genetic similarity and geographic proximity. For example, the two Mexican accessions, JCCR-24 and JCCR-31, clustered in different putative groups. Also, the two Indian accessions (JCCR-27 and JCCR-INDIA) did not seem to be related. J. curcas is widely cultivated and plants are exchanged commonly. Accessions from the same country may come from diverse origins and thus may be placed in different clades. Our analysis suggests that collection sites may not necessarily represent local germplasm, but genetically distinct lineages from different geographic regions. Material exchanges between American, 
272 African and Asian collections have occurred commonly over the last 200 years (Heller, 1996) and 273 may have resulted in founder effects in Africa and Asia (Henning, 2007; Lengkeek, 2007; 274 Pamidimarri \& Reddy 2014). For example, according to Pamidimarri \& Reddy (2014), Portuguese 275 seafarers introduced accessions from Mexico and Central America to India through two dispersal

276

routes: one brought $J$. curcas through Africa, Madagascar and finally to India, while the other passed through Spain on its way to India. These migration routes support our findings of a widely dispersed plant with little geographic structure.

The observed ML tree topology may be an artifact of the low level of genetic structure seen in our other analysis. Concurrently, low levels of inbreeding suggest considerable gene flow may be occurring in J. curcas in Costa Rica. Although our samples did not cluster similarly across analysis, a general lack of group structure was maintained throughout. The lack of consensus between clustering algorithms may be attributed to the nature of the different markers used. We analyzed multiple EST-SSR loci distributed throughout the genome (Davies \& Bermingham, 2002; Pamidimarri \& Reddy, 2014), and we are confident that we have accounted for a significant portion of the genetic variability in this species. Costa Rican diversity estimates may be improved by enriching the germplasm bank with more accessions from the Caribbean and southern parts of the country.

\section{Toxicity evaluation of $J$. curcas}

Our results show that only one of the accessions, Mexican JCCR-24, had all of the alleles that indicate non-toxicity. This accession was previously confirmed as non-toxic by in vivo evaluation (Basha \& Sujatha, 2007). JCCR-24 could be used as a parental plant in a breeding program to obtain dual-purpose non-toxic plants, thereby increasing the attractiveness of J. curcas as a biofuel 
295 plant (King et al., 2013). In other samples, only one or two toxic alleles were detected, depending

296 on the primers used. This may have been due to variations present in Costa Rican genotypes. SSR

297 markers are very polymorphic (Powell et al., 1996). The primers used to detect non-toxicity were

298 developed from Mexican, Asian and African accessions (Basha \& Sujatha, 2007; Phumichai et

$299 a l ., 2011)$ and their ability to detect toxicity may differ for genotypes from other parts of the world.

300 It is possible that other Costa Rican accessions have alleles that have not yet been identified as

301 indicative of non-toxicity, and in this case, the non-toxic nature of the accessions would have been

302 overlooked. In vivo evaluations are needed to confirm this hypothesis.

303

304 ACKNOWLEDGEMENTS

305 We thank the Estación Experimental Fabio Baudrit Moreno (EEFBM) of the Universidad de Costa 306 Rica for the collection and maintenance of the germplasm bank.

\section{ADDITIONAL INFORMATION}

DNA Submission to GenBank

The following information was supplied regarding the submission of DNA sequences: GenBank accession no.: KU561375, KU561376, KU561377, KU561378, KU561379, KU561380, KU561381, KU561382, KU561383, KU561384, KU561385, KU561386, KU561387, KU561388, KU561389, KU561390, KU561391, KU561393, KU561394, KU561395, KU561396, KU561397, KU561398, KU561399, KU561400, KU561401, KU561402, KU561403, KU561404, KU561405, KU561406, KU561407, KU561408, KU561409, KU561410, KU561411, KU561412, KU561413, 


\section{REFERENCES}

Abdulla JM, Janagoudar BS, Biradar DP, Ravikumar RL, Koti RV, Patil SJ. 2009. Genetic diversity analysis of elite Jatropha curcas L. genotypes using randomly amplified polymorphic DNA markers. Journal of Agricultural Science 22:293-295.

Ambrosi DG, Galla G, Purelli M, Barbi T, Fabbri A, Lucretti S, Sharbel TF, Barcaccia G. 2010. DNA Markers and FCSS Analysis Shed Light on the Genetic Diversity and Reproductive Strategy of Jatropha curcas L. Diversity 2:810-836 DOI10.3390/d2050810.

Avendaño R, García Díaz E, Valdez-Melara M, Chaves Solano N, Mora Villalobos A, Aguilar Cascante F, Williamson Benavides B, Solís-Ramos L. 2015. Genetic Diversity Analysis of Jatropha Species from Costa Rica Using AFLP Markers. American Journal of Plant Sciences 6:2426-2438 DOI10.4236/ajps.2015.614245.

Basili M, Fontini F. 2012. Biofuel from Jatropha curcas: Environmental sustainability and option value. Ecological Economics 78:1-8 DOI10.1016/j.ecolecon.2012.03.010.

Basha SD, Sujatha M. 2007. Inter and intrapopulation variability of Jatropha curcas (L.) characterized by RAPD and ISSR markers and development of population-specific SCAR markers. Euphytica 156:375-386 DOI 10.1007/s10681-007-9387-5.

Basha SD, Francis G, Becker K, Makkar HPS, Sujatha M. 2009. A comparative study of biochemical traits and molecular markers for assessment of relationships between Jatropha curcas germplasm in China. Biomass \& Bioenergy 7:1-12 DOI10.1016/j.plantsci.2009.03.008.

Botstein D, White RL, Skolnick M, Davis RW. 1980. Construction of a genetic linkage map in man using restriction fragment length polymorphisms. The American Journal of Human Genetics $32: 314-331$ 
341

342

343

344

345

346

347

348

349

350

351

352

353

354

355

356

357

358

359

360

361

362

Bressan EA, Sebbenn AM, Rodrigues Ferreira R, Lee TSG, Figueira A. 2013. Jatropha curcas

L. (Euphorbiaceae) exhibits mixed mating system, high correlate mating and apomixis. Tree Genetics \& Genomes 9:1089-197 DOI 10.1007/s11295-013-0623-y.

Carels N. 2013. Towards the domestication of Jatropha: The integration of science. In: Bahadur B, Sujatha M, Carels N (ed) Jatropha Challenges for a New Energy Crop: Volume II. Springer, New York, 263-299.

China Plant BOL Group, De-Zhu L, Lian-Ming G, Hong-Tao L, Hong W, Xue-Jun G, JianQuan L, Zhi-Duan C, Shi-Liang Z, Shi-Lin C, Jun-Bo Y, Cheng-Xin F, Chun-Xia Z, Hai-Fei Y, Ying-Jie Z, Yong-Shuai S, Si-Yun C, Lei Z, Kun W, Tuo Y, Guang-Wen D. 2011. Comparative analysis of a large dataset indicates that internal transcribed spacer (ITS) should be incorporated into the core barcode for seed plants. PNAS 108:19641-19646 DOI 10.1073/pnas.1104551108

Colombo C, Second G, Charrier A. 2000. Diversity within American cassava germplasm based on RAPD markers. Genetics and Molecular Biology 23:189-199.

Cova V, Perini D, Soglio V, Komjanc M, van de Weg E, Glessler C, Gianfranceschi L. 2012. Exploiting expressed sequence tag database for mapping markers associated with fruit development and fruit quality in apple. Molecular Breeding 29:699-715.

Davies N, Bermingham E. 2002. The historical biogeography of two Caribbean butterflies (Lepidoptera: heliconiidae) as inferred from genetic variation at multiple loci. Evolution 56:573589.

Ellis JR, Burke JM. 2007. EST-SSRs as a resource for population genetic analysis. Heredity 99:125-132. 
Goldstein DB, Ruiz Linares A, Cavalli Sforza LL, Feldman MW. 1995. An evaluation of genetic distances for use with microsatellite loci. Genetics 139:463-471.

Grativol C, da Fonseca Lira-Medeiros C, Hemerly AS, Ferreira PCG. 2010. High efficiency and reliability of inter-simple sequence repeats (ISSR) markers for evaluation of genetic diversity in Brazilian cultivated Jatropha curcas L. accessions. Molecular Biology Reports 38:4245-4256 DOI 10.1007/s11033-010-0547-7.

Heller J. 1996. Physic Nut Jatropha curcas L. Promoting the Conservation and use of Underutilized and Neglected Crops. Rome: IPGRI, 10-11.

Henning RK. 2007. Jatropha curcas L. In: van der Vossen HAM, Mkamilo GS, ed. Plant Resources of the Tropical Africa: Volume I. Vegetable oils PROTA Fondation, Wageningen, The Netherlands, 14:116-122.

Insanu M, Dimaki C, Wilkins R, Brooker J, van der Linde P, Kayser O. 2013. Rational use of Jatropha curcas L. in food and medicine: from toxicity problems to safe applications. Phytochemistry review 12:107-119.

Islam A, Taufiq-Yap YH, Chu CH, Ravindra P, Chan ES. 2013. Transesterification of palm oil using KF and NaNO3 catalysts supported on spherical millimetric $\gamma$-A12O3. Renewable Energy $59: 23-29$.

Jongschaap REE, Corré WJ, Bindraban PS, Brandenburg, WA. 2007. Claims and Facts. In: Jatropha curcas L.: Global Jatropha curcas Evaluation, Breeding and propagation programme. Report 158 Plant Research International BV, Wageningen, The Netherlands, 42.

King AJ, Montes LR, Clarke JG, Affleck J, Li Y, Witsenboer H, van der Vossen E, van der Linde P, Tripathi Y, Tavares E, Shukla P, Rajasekaran T, van Loo EN, Graham IA. 2013. Linkage mapping in the oilseed crop Jatropha curcas L. reveals a locus controlling the 
386 biosynthesis of phorbol esters which cause seed toxicity. Plant Biotechnology J 11:986-996 DOI

387

388

389

390

391

392

393

394

395

396

397

398

399

400

401

402

403

404

405

406 10.1111/pbi.12092.

King AJ, Montes LR, Clarke JG, Itzep J, Perez CA, Jongschaap RE, Visser RG, van Loo EN, Graham I. 2015. Identification of QTL markers contributing to plant growth, oil yield and fatty acid composition in the oilseed crop Jatropha curcas L. Biotechnology for Biofuels 8:1-17 DOI 10.1186/s13068-015-0326-8.

Lengkeek AG. 2007. The Jatropha curcas agroforestry strategy of Mali Biocarburant SA. In: Proceedings of the FACT Seminar on Jatropha curcas L. Agronomy and Genetics. Wageningen, The Netherlands, 597.

Liu K, Muse SV. 2005. PowerMarker: an integrated analysis environment for genetic marker analysis. Bioinformatics 21:228-2129 DOI 10.1093/bioinformatics/bti282.

Maghuly F, Jankowicz-Cieslak J, Parbinger S, Till BJ, Laimer M. 2015. Geographic origin is not supported by the genetic variability found in a large living collection of Jatropha curcas with accessions from three continents. Biotechnology Journal 10:536-551 DOI 10.1002/biot.201400196.

Makker HPD, Becker K. 2015. Jatropha curcas, a promising crop for the generation of biodisel and value-added coproducts. European Journal of Lipid Science and Technology 11:773-787 DOI 10.1002/ejlt.200800244.

Mastan S, Sudheer P, Rahman H, Ghosh A, Rathore M, Ravi Prakash C, Chikara J. 2012. Molecular characterization of intra-population variability of Jatropha curcas L. using DNA based molecular markers. Molecular Biology Reports 39:4383-4390 DOI 10.1007/s11033-011-1226-z. 
407 408

409

410

411

412

413

414

415

416

417

418

419

420

421

422

Möller EM, Bahnweg G, Sandermann H, Geiger HH. 1992. A simple and efficient protocol for isolation of high molecular weight DNA from filamentous fungi, fruit bodies, and infected plant tissues. Nucleic Acids Research 22: 6115-6116.

Montes Osorio LR, Torres Salvador AF, Jongschaap REE, Azurdia C, Berduo J, Trindade

LM, Visser RGF, Loo EN van. 2014. High level of molecular and phenotypic biodiversity in Jatropha curcas from Central America compared to Africa, Asia and South America. BMC Plant Biology 14:19 DOI10.1186/1471-2229-14-77.

Nieto-Feliner G, Roselló JA. 2007. Better the devil you know? Guideline for insightful utilization of nrDNA ITS in species-level evolutionary studies in plants. Molecular Phylogenetics and Evolution 44:911-919.

Openshaw K. 2000. A review of Jatropha curcas: an oil plant of unfulfilled promise. Biomass \& Bioenergy 19:1-15 DOI 10.1016/S0961-9534(00)00019-2.

Ovando-Medina I, Espinosa GF, Nuñez FJ, Salvador FM. 2011. Genetic variation in Mexican Jatropha curcas L. estimated with seed oil fatty acids. Journal of Oleo Science 60:301-311.

Ovando-Medina I, Adriano-Anaya L, Vásquez-Ovando A. 2013. Genetic diversity of Jatropha curcas in southern Mexico. In: Bahadur B, Sujatha M, Carels N (ed) Jatropha Challenges for a New Energy Crop. Springer, New York, pp 263-299,

Pamidimarri SDV, Chattopadhyay B, Reddy MP. 2008. Genetic divergence and phylogenetic analysis of genus Jatropha based on nuclear ribosomal DNA ITS sequence. Molecular Biology Reports 36:1929-1935 DOI 10.1007/s11033-008-9401-6.

Pamidimarri SDV, Reddy MO. 2014. Phylogeography and molecular diversity analysis of Jatropha curcas L. and the dispersal route revealed by RAPD, AFLP and nrDNA-ITS analysis. Molecular Biology Reports 41:3225-34 DOI 10.1007/s11033-014-3185-7. 
430 Peakall R, Smouse PE. 2012. GenAlEx 6.5: genetic analysis in Excel. Population genetic

431 software for teaching and research-an update. Bioinformatics 28:2537-2539.

432 Pecina-Quintero V, Amaya JL, Zamarripa A, Montes N, Núñez C, Solís J. 2011. Molecular 433 characterization of Jatropha curcas L. genetic resources from Chiapas, México through AFLP

434 435

436

437

438

439

440

441

442

443

444

445

446

447

448

449

450

451

452

markers. Biomass \& Bioenergy 35:1897-1905 DOI 10.1016/j.biombioe.2011.01.027.

Pecina-Quintero V, Anaya-Lopez JL, Zamarripa-Colmenero A, Nunez-Colin CA. 2014. Genetic structure of Jatropha curcas L. in Mexico and probable center of origin. Biomass \& Bioenergy 60:147-155 DOI 10.1016/j.biombioe.2013.11.005.

Phumichai C, Phumichai T, Kongsiri N, Wongkaew A, Sripichit P, Kaveeta R. 2011. Isolation of 55 microsatellite markers for Jatropha curcas and its closely related species. Biologia Plantarum

$55: 387-390$.

Powell W, Morgante M, Andre C, Hanafey M, Vogel J, Tingey S, Rafalski A. 1996. The comparison of RFLP, RAPD, AFLP and SSR (microsatellite) markers for germplasm analysis. Molecular Breeding 2:225-238.

Ram J, Kumar A, Bhatt J. 2004. Plant diversity in six forest types of Uttaranchal, Central Himalaya, India. Current Science 86:975-978.

Raposo RS, Souza IGB, Veloso MEC, Kobayashi AK, Laviola BG, Diniz FM. 2014. Development of novel simple sequence repeat markers from a genomic sequence survey database and their application for diversity assessment in Jatropha curcas germplasm from Guatemala. Genetics and molecular research 13:6099-6106 DOI 10.4238/2014.August.7.25.

Rosado TB, Laviola BG, Faria DA, Pappas MR, Bhering LL, Quirino B, Grattapaglia D. 2010. Molecular markers reveal limited genetic diversity in a large germplasm collection of the 
453 biofuel crop Jatropha curcas L. in Brazil. Crop Science 50:2372-2382 DOI $454 \quad 10.2135 /$ cropsci2010.02.0112.

455 Santorum JM, Darriba D, Taboada GL, Posada D. 2014. jmodeltest.org: selection of nucleotide 456 substitution models on the cloud. Bioinformatics 30:1310-1311 DOI 457 10.1093/bioinformatics/btu032.

458 Smith JSC, Chin ECL, Shu H, Smith OS, Wall SJ, Senior ML, Mitchell SE, Kresovich S, 459

Ziegle J. 1997. An evaluation of the utility of SSR loci as molecular markers in maize (Zea mays L.): comparisons with data from RFLPs and pedigree. Theoretical and Applied Genetics 95:163173.

Song YP, Jiang XB, Zhang M, Wang ZL, Bo WH, An XM, Zhang DQ, Zhang ZY. 2012. Differences of EST-SSR and genomic-SSR markers in assessing genetic diversity in poplar. Forestry Studies in China 14:1-7 DOI 10.1007/s11632-012-0106-5.

Sun QB, Li LF, Li Y, Wu GJ, Ge XJ. 2008. SSR and AFLP markers reveal low genetic diversity in the biofuel plant Jatropha curcas in China. Crop Science 48:1865-1871 DOI 10.2135/cropsci2008.02.0074.

Tamura K, Stecher G, Peterson D, Filipski A, Kumar S. 2013. MEGA6: Molecular Evolutionary Genetics Analysis Version 6.0. Molecular Biology and Evolution 30:2725-2729 DOI 10.1093/molbev/mst197.

Tatikonda L, Wani PS, Kannan S, Beerelli N, Sreedevi KT, Hoisington AD. 2009. AFLP based molecular characterization of an elite germplasm collection of Jatropha curcas L., biofuel plant. Plant Science 176:505-513.

Tavaré S. 1986. Some probabilistic and statistical problems in the analysis of DNA sequences. In: American Mathematical Society. Lectures on Mathematics in the Life Sciences 17:57-86. 
476

477

478

479

480

481

482

483

484

485

486

487

488

489

490

491

492

493

494

495

496

497

498

To H, Grafton Q. 2015. Oil prices, biofuels production and food security: past trends and future challenges. Food Security 7:323-336 DOI 10.1007/s12571-015-0438-9

van Oosterhout C, Hutchinson WF, Wills DP, Shipley P. 2004. MICRO-CHECKER: software for identifying and correcting genotyping errors in microsatellite data. Molecular Ecology Notes 4:535-538 DOI 10.1111/j.1471-8286.2004.00684.x.

Varshney RK, Graner A, Sorrells ME. 2005. Genic microsatellite markers in plants: features and applications. Trends in Biotechnology 23:48-55 DOI 10.1016/j.tibtech.2004.11.005.

Vera-Castillo YB, Cuevas JA, Valenzuela-Zapata AG, Urbano B, Gonzalez-Andres F. 2014. Biodiversity and indigenous management of the endangered non-toxic germplasm of Jatropha curcas L. in the Totonacapan (Mexico), and the implications for its conservation. Genetic Resources and Crop Evolution 61:1263-1278 DOI: 10.1007/s10722-014-0109-2.

Vischi M, Raranciuc S, Baldini M. 2013. Evaluation of genetic diversity between toxic and non toxic Jatropha curcas L. accessions using a set of simple sequence repeat (SSR) markers. African Journal of Biotechnology 12: 265-274 DOI 10.5897/AJB12.2656.

Wen M, Wang H, Xia Z, Zou M, Lu C, Wang W. 2010. Development of EST-SSR and genomic SSR markers to assess genetic diversity in Jatropha curcas L. BMC Research Notes 3:4210 DOI 10.1186/1756-0500-3-42.

Yadav HK, Ranjan A, Asif MH, Mantri S, Sawant SV, Tuli R. 2011. EST-derived SSR markers in Jatropha curcas L. development, characterization, polymorphism, and transferability across the species/genera. Tree Genetics \& Genomes 7:207-219 DOI: 10.1007/s11295-010-0326-6. 


\section{List of tables}

Table 1. Germplasm bank identification number, geographical collection sites and Genbank Accession number of nrDNA-ITS region for each of the $J$. curcas accessions in the Fabio Baudrit Experimental Station used in the study.

Table 2. EST-SSR and G-SSR primers used for evaluation of Jatropha curcas germplasm.

Table 3. Primers used to evaluate toxicity of accessions in the germplasm bank.

*NA: No amplification expected

Table 4. Parameters of genetic diversity and information contents of eighteen EST-SSR markers and one SSR used to analyze $50 \mathrm{~J}$. curcas accessions.

*He: Heterozygosity, PIC: Polymorphism information content, f: inbreeding coefficient

List of figures

Fig. 1. Map of Costa Rica with sites where Jatropha curcas accessions were collected. A) North Pacific Region. B) Central Pacific Region.

Fig. 2. Neighbor-Joining (NJ) tree based on a genetic distance matrix from 19 microsatellite data from 50 germplasm accessions of $J$. curcas.

Fig. 3. Principal coordinate analysis created with GenAlEx based on the $\delta \mu^{2}$ genetic distance estimated in the POPULATIONS software with 19 microsatellites from 50 germplasm accessions of J. curcas from the Costa Rican germplasm bank evaluated in this study.

Fig. 4. Maximum likelihood phylogenetic tree generated with 60 Jatropha curcas samples. Analyzed sequences represent the nrDNA-ITS region. The tree was constructed with the GTR model using a jModelTest analysis with 3000 bootstraps and uniform substitution rates in the MEGA 6.0 software. Only bootstrap values higher than $50 \%$ are shown. The bar indicates the 
523 substitutions per site. Blue boxes show the sequences obtained from the current work in Costa

524 Rica. Other accessions were obtained from Genbank for comparison. 
Figure 1

Map of Costa Rica

Map of Costa Rica with sites where Jatropha curcas accessions were collected. A) North Pacific Region. B) Central Pacific Region

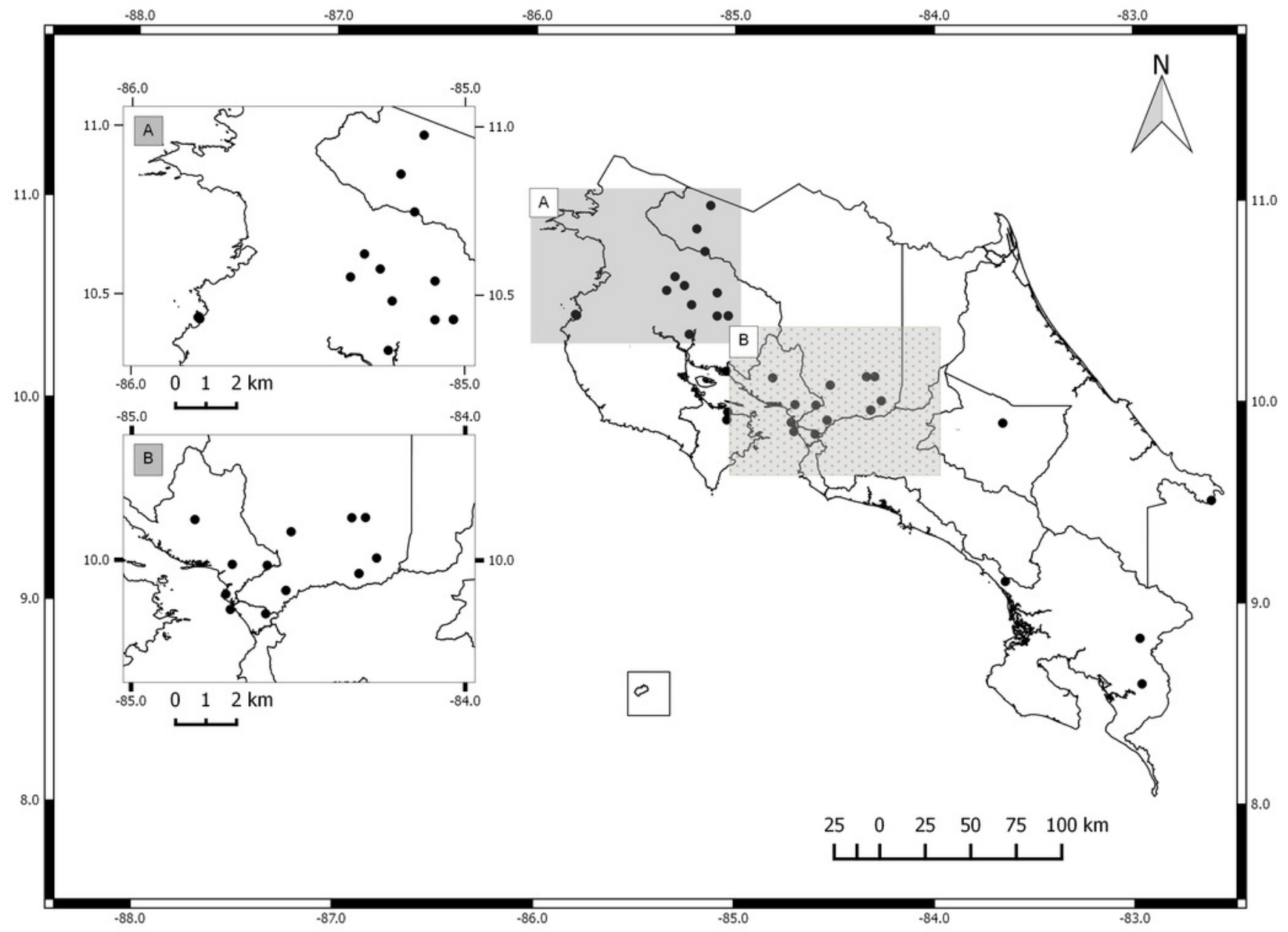


Figure 2

Neighbor-Joining (NJ) tree

Neighbor-Joining (NJ) tree based on a genetic distance matrix from 19 microsatellite data from 50 germplasm accessions of $J$. curcas. 


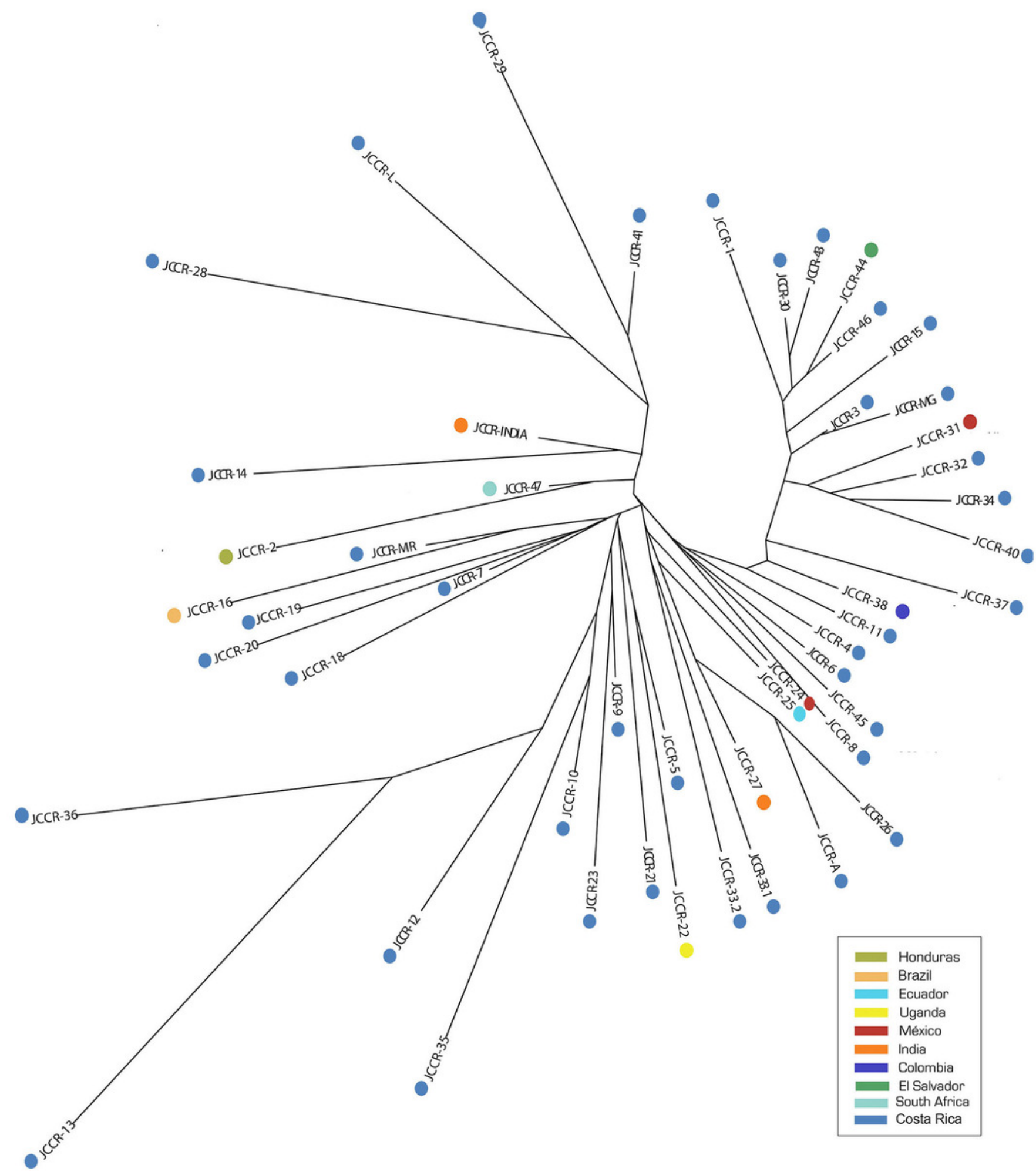


Figure 3

\section{Principal coordinate analysis}

Principal coordinate analysis created with GenAlEx based on the $\delta \mu^{2}$ genetic distance estimated in the Populations software with 19 microsatellites from 50 germplasm accessions of $J$. curcas from the Costa Rican germplasm bank evaluated in this study.

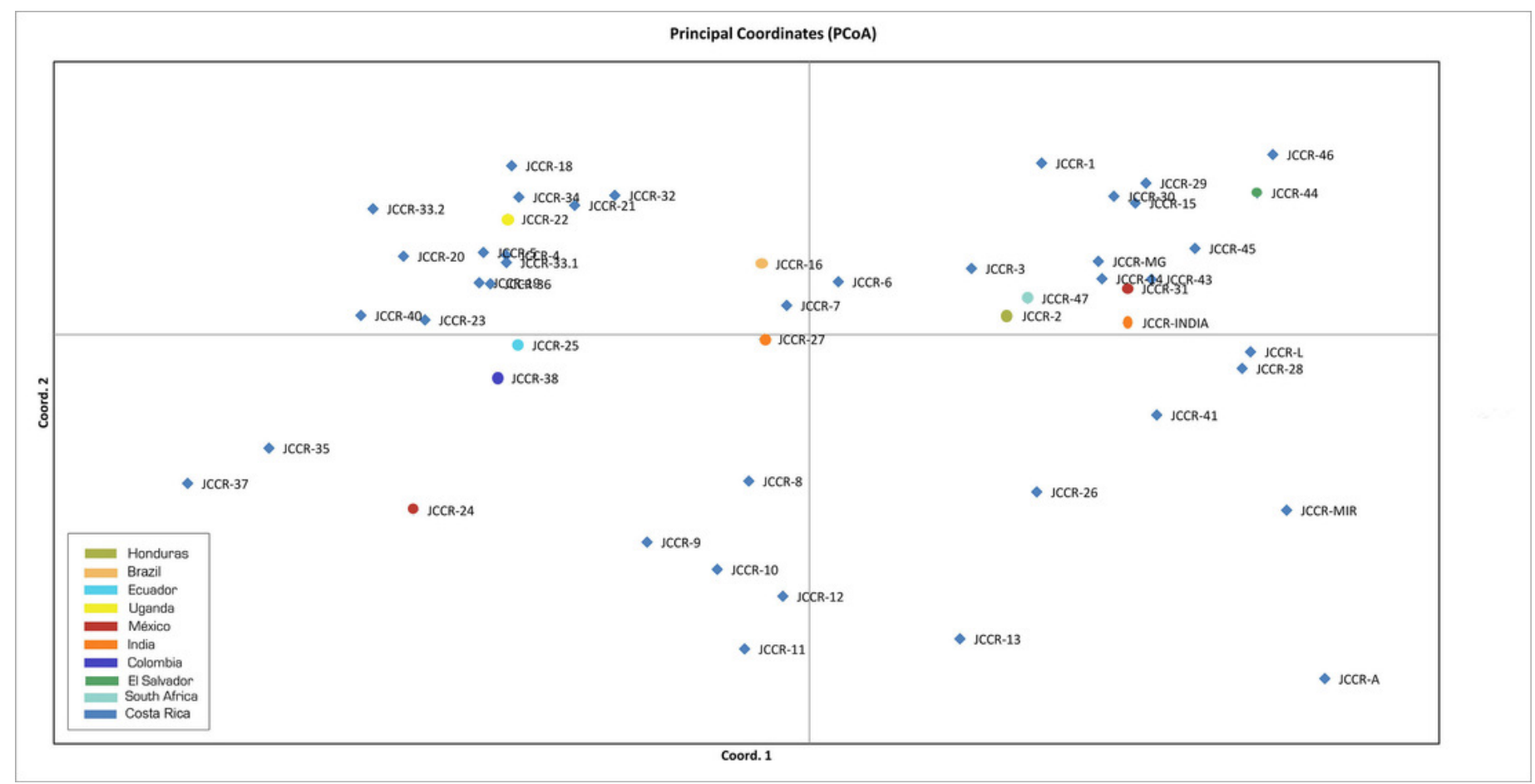




\section{Figure 4}

Maximum likelihood phylogenetic tree

Maximum likelihood phylogenetic tree generated with 60 Jatropha curcas samples. Analyzed sequences represent the nrDNA-ITS region. The tree was constructed with the GTR model using a jModelTest analysis with 3000 bootstraps and uniform substitution rates in the MEGA 6.0 software. Only bootstrap values higher than $50 \%$ are shown. The bar indicates the substitutions per site. Blue boxes show the sequences obtained from the current work in Costa Rica. Other accessions were obtained from Genbank for comparison.

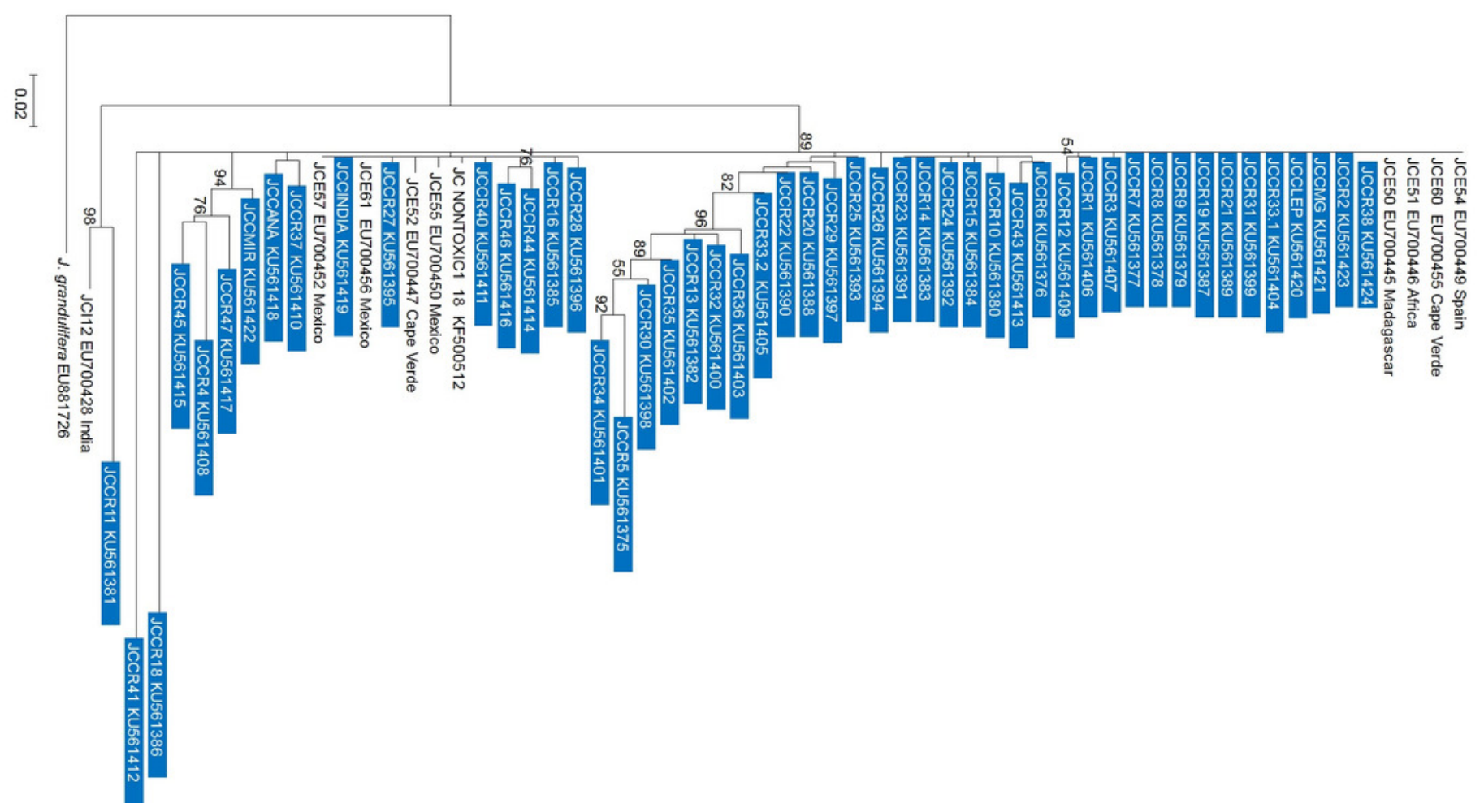




\section{Table $\mathbf{1}$ (on next page)}

Germplasm bank information

Germplasm bank identification number, geographical collection sites and Genbank Accession number of nrDNA-ITS region for each of the J. curcas accessions in the Fabio Baudrit Experimental Station used in the study. 


\begin{tabular}{|c|c|c|c|}
\hline Germplasm code & Country & Location & $\begin{array}{c}\text { Genbank accesion } \\
\text { number }\end{array}$ \\
\hline JCCR-1 & Costa Rica & Orotina & KU561406 \\
\hline JCCR-3 & Costa Rica & Orotina & KU561407 \\
\hline JCCR-4 & Costa Rica & San Mateo & KU561408 \\
\hline JCCR-5 & Costa Rica & Cañas & KU561375 \\
\hline JCCR-6 & Costa Rica & San Antonio & KU561376 \\
\hline JCCR-7 & Costa Rica & Cañas & KU561377 \\
\hline JCCR-8 & Costa Rica & Abangares & KU561378 \\
\hline JCCR-9 & Costa Rica & Guapinol & KU561379 \\
\hline JCCR-10 & Costa Rica & Cañas & KU561380 \\
\hline JCCR-11 & Costa Rica & San Antonio & KU561381 \\
\hline JCCR-12 & Costa Rica & San Mateo & KU561409 \\
\hline JCCR-13 & Costa Rica & Orotina & KU561382 \\
\hline JCCR-14 & Costa Rica & Turrubares & KU561383 \\
\hline JCCR-15 & Costa Rica & Abangares & KU561384 \\
\hline JCCR-18 & Costa Rica & Bagaces & KU561386 \\
\hline JCCR-19 & Costa Rica & Cañas & KU561387 \\
\hline JCCR-20 & Costa Rica & San Vito & KU561388 \\
\hline JCCR-21 & Costa Rica & Capulin & KU561389 \\
\hline
\end{tabular}




\begin{tabular}{|c|c|c|c|}
\hline JCCR-23 & Costa Rica & San Antonio & KU561391 \\
\hline JCCR-26 & Costa Rica & Capulin & KU561394 \\
\hline JCCR-28 & Costa Rica & Upala & KU561396 \\
\hline JCCR-29 & Costa Rica & Bagaces & KU561397 \\
\hline JCCR-30 & Costa Rica & Coto 54 & KU561398 \\
\hline JCCR-32 & Costa Rica & Bagaces & KU561400 \\
\hline JCCR-33.1 & Costa Rica & Los Santos & KU561404 \\
\hline JCCR-33.2 & Costa Rica & Los Santos & KU561405 \\
\hline JCCR-34 & Costa Rica & FabioBaudrit & KU561401 \\
\hline JCCR-35 & Costa Rica & Abangares & KU561402 \\
\hline JCCR-36 & Costa Rica & Turrubares & KU561403 \\
\hline JCCR-37 & Costa Rica & Unknown & KU561410 \\
\hline JCCR-40 & Costa Rica & Lagunilla & KU561411 \\
\hline JCCR-41 & Costa Rica & CATIE & KU561412 \\
\hline JCCR-43 & Costa Rica & Turrubares & KU561413 \\
\hline JCCR-45 & Costa Rica & Unknown & KU561415 \\
\hline JCCR-46 & Costa Rica & Diquis & KU561416 \\
\hline JCCR-MIR & Costa Rica & Miramar & KU561422 \\
\hline JCCR-ANA & Costa Rica & Anabel & KU561418 \\
\hline JCCR-MG & Costa Rica & Montaña Grande & KU561421 \\
\hline JCCR-LEP & Costa Rica & Lepanto & KU561420 \\
\hline
\end{tabular}




\begin{tabular}{cccc}
\hline JCCR-2 & Honduras & Unknown & KU561423 \\
JCCR-16 & Brazil & Unknown & KU561385 \\
JCCR-22 & Uganda & Unknown & KU561390 \\
JCCR-24 & Mexico & Unknown & KU561392 \\
JCCR-31 & Mexico & Unknown & KU561399 \\
JCCR-25 & Ecuador & Manabí & KU561393 \\
JCCR-27 & India & Unknown & KU561395 \\
JCCR-INDIA & India & Unknown & KU561419 \\
JCCR-38 & Colombia & Unknown & KU561424 \\
JCCR-44 & El Salvador & Unknown & KU561414 \\
& South Africa & Unknown & \\
\hline
\end{tabular}

2 


\section{Table 2 (on next page)}

Primers used for evaluation of J. curcas

EST-SSR and G-SSR primers used for evaluation of Jatropha curcas germplasm. 


\begin{tabular}{|c|c|c|c|c|}
\hline ID & Forward Primer & Reverse Primer & $\begin{array}{c}\mathbf{T}_{\mathrm{A}} \\
\left({ }^{\circ} \mathbf{C}\right)^{*}\end{array}$ & Expected size (bp) \\
\hline JESR-001 & AACCACAGGAGTTGGTAATG & GAAAGAAGCAACAGAAATGG & 50 & 307 \\
\hline JESR-028 & ACTTCCTTCAGATCATGCAC & CTGGGTAATCTTGTTCCAAA & 52 & 292 \\
\hline JESR-047 & GTTGATACTGGAAGTGAGCC & TGTGTTCAAAGGTGATGAGA & 52 & 398 \\
\hline JESR-086 & TCССТСТССТTCAGATTAAA & ATGATAGCCAAACAGCAACT & 54 & 333 \\
\hline JESR-092 & CTCTGAGAATTGAACCATCC & GGGAACAAAGAAATTACTGG & 54 & 378 \\
\hline JESR-093 & CACCTCCCATTAGGGTTT & CTAATCGACGCTGATAATCC & 54 & 239 \\
\hline JESR-095 & AATGAGTCTGACAATCAGGG & GCATGCTCTGTTCTGCTT & 54 & 336 \\
\hline JESR-096 & ACACAAACACAATCAACAGC & CGCGACTCACTTTGTATGTA & 54 & 244 \\
\hline JESR-098 & AGATCACAAGGATCACAAGG & GCAGTTGTCAAACACTAGCA & 54 & 290 \\
\hline JESR-099 & ATAATGGCAAACAAGTGGTC & TGGTAGTGTTGTTCTTGCAG & 54 & 305 \\
\hline JESR-101 & АТССТАACACAGTTGCCATC & AААCТСААССАААCСАCAAC & 54 & 230 \\
\hline JESR-102 & ATCCTTCTGCAGTAGCCATA & TTATATGCTACACATCAACCTG & 54 & 278 \\
\hline JESR-103 & CAAGTTCGAGGAGTACAAGG & TGTTACAACGAGATGAGTGC & 54 & 292 \\
\hline JESR-104 & CCACAGTTCATCCTCAATTT & GATATTCACTCTGGAACCCA & 54 & 308 \\
\hline JESR-118 & CTAAAGGCTGTGAAGAAGGA & TCCGAGCCAATTTCTTATTA & 54 & 276 \\
\hline JESR-161 & AAGAAGTGTATGGGTTGCAC & TACGATACCTAGGGCTACGA & 56 & 323 \\
\hline JESR-162 & ACTGATGGGTATGTGAGAGG & TTCTTCATCATGGCTACCTT & 56 & 220 \\
\hline JESR-163 & CAGAAACGGAGAGGTCTG & AGATTGGAAGAGGAGAGGAG & 56 & 144 \\
\hline JESR-164 & AGCCCAGTCTCGCGGAAG & CAGTTCCCTTCAGAAGCTC & 56 & 231 \\
\hline JESR-178 & CTTTAGTCCACCTCAAGTGC & TGCAGCAATCAACTCTACTG & 56 & 375 \\
\hline JSSR-203 & ATCCTTGCCTGACATTTTGC & TTCGCAGAGTCCAATTGTTG & 55 & 210 \\
\hline
\end{tabular}




\section{Table 3 (on next page)}

Primers used to evaluate toxicity of accessions

Primers used to evaluate toxicity of accessions in the germplasm bank. 
1

\begin{tabular}{|c|c|c|c|c|}
\hline $\begin{array}{c}\text { Primer } \\
\text { ID }\end{array}$ & Primer sequences & $\mathbf{T}_{\mathrm{m}}\left({ }^{\circ} \mathbf{C}\right)$ & $\begin{array}{c}\text { Expected size non- } \\
\text { toxic (bp) }\end{array}$ & $\begin{array}{c}\text { Expected size } \\
\text { toxic (bp) }\end{array}$ \\
\hline $\mathrm{JCT} 27$ & $\begin{array}{l}\text { F: 5'-CATTAGAATGGACGGCTA-3' } \\
\text { R: 5'-GCGTGAAGCTTTGATTTGA-3' }\end{array}$ & 60 & 259 & 253 \\
\hline JcSSR-26 & $\begin{array}{l}\text { F: 5'-CATACAAAGCCTTGTCC-3' } \\
\text { R: 5'-AACAGCATAATACGACTC-3' }\end{array}$ & 55 & 210 & 230 \\
\hline JCT31 & $\begin{array}{l}\text { F: 5'-TGGAAAACGAATGAGGCTCT-3' } \\
\text { R: 5'-GGACACTCTGGAAAGGAACG-3' }\end{array}$ & 59 & 214 & 208 \\
\hline ISPJ1 & $\begin{array}{l}\text { F: 5'-GAGAGAGAGAGAGAGGTG-3' } \\
\text { R-5'-GAGAGAGAGAGAGAAAACAAT-3' }\end{array}$ & 54 & $\mathrm{NA}^{*}$ & 543 \\
\hline ISPJ2 & $\begin{array}{l}\text { F- 5'GAGAGAGAGAGTTGGGTG-3' } \\
\text { R-5'AGAGAGAGAGAGCTAGAGAG-3' }\end{array}$ & 54 & 1096 & NA \\
\hline
\end{tabular}




\section{Table 4(on next page)}

Parameters of genetic diversity information obtained 


\begin{tabular}{|c|c|c|c|}
\hline SSR name & $\mathrm{He}^{*}$ & PIC* & $f^{*}$ \\
\hline JEST-01 & 0.375 & 0.551 & 0.411 \\
\hline JEST-28 & 0 & 0.043 & 0.001 \\
\hline JEST-47 & 0.050 & 0.048 & -0.0129 \\
\hline JEST-86 & 0 & 0.336 & 0.001 \\
\hline JEST-92 & 0.814 & 0.370 & -0.654 \\
\hline JEST-93 & 0.327 & 0.250 & -0.160 \\
\hline JEST-95 & 0.217 & 0.175 & -0.111 \\
\hline JEST-96 & 0.380 & 0.260 & -0.225 \\
\hline JEST-98 & 0.043 & 0.114 & 0.650 \\
\hline JEST-99 & 0.280 & 0.236 & -0.110 \\
\hline JEST-101 & 0.500 & 0.357 & -0.062 \\
\hline JEST-102 & 0.325 & 0.235 & -0.182 \\
\hline JEST-118 & 0.313 & 0.228 & -0.175 \\
\hline
\end{tabular}




\begin{tabular}{cccc}
\hline JEST-161 & 0.043 & 0.042 & -0.011 \\
JEST-162 & 0.500 & 0.677 & 0.300 \\
JEST-163 & 0.245 & 0.192 & -0.129 \\
JEST-164 & 0.721 & 0.355 & -0.555 \\
JEST-178 & 0.512 & 0.364 & -0.058 \\
JSSR-203 & 0.933 & 0.375 & -0.862 \\
\hline Mean & 0.346 & 0.274 & -0.102 \\
\hline
\end{tabular}

2 * He: Heterozygosity, PIC: Polymorphism information content, f: inbreeding coefficient

3

4

5

6

7

8

9

10 